\title{
Das Wichtigste in wenigen Sätzen
}

Digitale Durchstarter werden durch den gezielten Einsatz von digitalen Tools ihre Effizienz steigern und Kunden positiv verblüffen. Dies mündet in steigende Erträge - nicht ausschließlich begründet durch gesunden Menschenverstand, sondern auch durch die in diesem essential dargelegten Fakten. 